\title{
LA VIDA COTIDIANA DE LOS REGIDORES MADRILEÑOS DE LA SEGUNDA MITAD DEL SIGLO XVI
}

\author{
Ana GUERRERO MAYLLO \\ U.N.E.D. (Madrid)
}

Cualquier acontecimiento histórico, sea político, económico, social o cultural, difícilmente puede interpretarse sin hacer referencia a los hombres que lo protagonizan. El individuo o el grupo, todo depende de que lo estudiado tenga una impronta personal o colectiva, viene a configurarse en el fondo como la parte más esencial, si no definitiva, del hecho que se va a historiar, sin desdeñar, claro está, circunstancias espacio/temporales o de otra índole que, a su vez, van a mediatizar aquél en no pequeña medida. Esta consideración adquiere auténtico realce cuando el historiador aborda el estudio de las instituciones, porque su funcionamiento no se puede comprender si no se valoran aspectos de tanta importancia como la procedencia social de sus componentes, los parentescos, las alianzas, las fortunas, la psicología colectiva y los hábitos culturales; dicho de otro modo, es preciso inquirir en el vivir cotidiano de quienes tienen en las manos la capacidad y la facultad de gobernar una monarquía, un reino o un concejo. Es este objetivo, precisamente, el que perseguimos con el trabajo que ahora presentamos, centrado en un grupo de poder bien definido: los regidores madrileños de la segunda mitad del siglo XVI ${ }^{1}$.

\section{PERFIL SOCIOLOGICO DE LOS REGIDORES MADRILEÑOS}

En la compleja estratificación social de la España del siglo XVI, donde los miembros de cada estamento ocupan lugares distintos en razón de su riqueza, hemos de considerar a los integrantes de las regidurías ciudadanas como un sector privilegiado. Aunque no siempre se puede hablar de concejos aristocráticos, lo cierto es que el predominio de hidalgos o de vástagos de títulos nobiliarios, les concede dicho carácter.

1 Este trabajo constituye una breve síntesis de algunos aspectos de mi Tesis Doctoral, titulada: "Oligarquía y gobierno municipal en la Corte de la Monarquía Hispánica. El concejo de Madrid entre 1560 y 1606". UNED,1990. Inédita. 
En Madrid, del conjunto de regidores, oriundos en su mayoría de la Villa y su término ${ }^{2}$, pertenece a la nobleza media aproximadamente un 61 ' $4 \%$, de los cuales ocho son títulos nobiliarios, por lo general de reciente creación, exceptuando al Príncipe de Eboli y al Duque de Lerma; unos quince capitulares, entre los que destacan Cosme Ruíz Embito, Joan María Sauli, Antonio Vázquez Vuelta, Pedro Villamor o los Medina proceden del mundo de los negocios; y a la burocracia, incluidos algunos letrados desprovistos de linaje pero con recursos económicos cuantiosos y que, a través de las regidurías, aspiraban a ennoblecerse, están ligados 33 ediles, entre los que encontramos personajes tan relevantes como los secretarios Pedro Franqueza, Juan Ibarra, Juan Ruíz de Velasco y Juan Vázquez Salazar, o los licenciados Diego de la Canal, Bernardino de Matienzo y Gilberto de Bedoya, por citar algunos nombres. De hecho, el 33'6\% de los 171 regidores que integran el concejo entre 1560 y 1606 tuvo dificultades para ser reconocidos hidalgos, como por ejemplo les ocurrió a los Barrionuevo de Peralta y a los Henao 3 .

No obstante, estas desigualdades estamentales van desapareciendo mediante el matrimonio, de suerte que en el transcurso de una, a lo sumo dos generaciones, las diferencias sociales entre los miembros del Regimiento apenas si son notorias, como lo demuestran los casos del Licenciado García Barrionuevo de Peralta, cuyo nieto ostentó el título de Marqués de Cusano, o el de San Juan de Sardaneta, que emparentó con la ilustre casa de los Mendoza de Guadalajara ${ }^{4}$. Ninguna prueba tan concluyente al respecto como la de que el $63^{\prime} 7 \%$ de los regidores estudiados están vinculados entre sí por lazos familiares, lo que nos permite hablar, sin temor, de una elevada endogamia en el grupo ${ }^{5}$. A ello contribuye, por otro lado, la práctica, muy extendida, de transmitir el oficio por vía de renuncia - o por herencia cuando son adquiridos por juro de heredad-, ya que normalmente recaen en el seno de la misma familia, por línea directa ( padres-hijos-hermanos) o colateral (tíos-sobri-

2 El 62'9\% de los regidores son oriundos de Madrid villa; el 15'5\% lo son de su término; a Castilla la Vieja pertenece el 6’2\%; de Castilla la Nueva procede el 4'6\%; a Andalucía le corresponde idéntico porcentaje; a Vascongadas y a Cataluña deben sus orígenes un 1'6\%, respectivamente, mientras que en Extremadura tan sólo se registra un 0 '7\%.

3 Varios integrantes de la familia Barrionuevo de Peralta se ven precisados a litigar su hidalguía, sobre ello en Archivo de la Real Chancillería de Valladolid (ACV), Sala de Hijosdalgo, 303-1; 1367-13. Archivo Histórico de Protocolos Notariales de Madrid (APM), Protocolo 392 fol. 391; 584 fol. 1475. Los Henao, en ACV, Sala de Hijosdalgo, 1396-118.

4 ALVAREZ Y BAENA, J.: Hijos de Madrid ilustres en Santidad, dignidad, armas, ciencias y artes, Madrid, 1789-1791. T. II, pág. 287. San Juan de Sardaneta había litigado por su hidalguía, lo que no fue obstáculo para su matrimonio con Juana de Mendoza, APM, Protocolo 520 fol. 21. Sobre tan ilustre familia, LAYNA SERRANO, F.: Historia de Guadalajara y sus Mendozas en los siglos XV y XVI, Madrid, 1942.

5 Esta característica, si no tan exagerada, se puede observar en otros concejos, tal y como señalan: BENNASSAR, B.: Valladolid en el Siglo de Oro. Una ciudad de Castilla y su entorno agrario en el siglo XVI, Valladolid, 1989, pág. 375 y ss. YUN CASALILLA, B: Sobre la transición al capitalismo en Castilla. Economia y sociedad en la Tierra de Campos (1500-1830), Junta de Castilla y León, 1987, pág. 224. PEREIRO, P.: Vida cotidiana y elite local. Málaga a mediados del Siglo de Oro, Málaga, 1987, págs, 147 y 154.SANCHEZ PEREZ, A.J.: Poder municipal y oligarquía. El concejo cacereño en el siglo XVII, Cáceres, 1987, pág. 54. CHACON JIMENEZ, F.: Murcia en la centuria del Quinientos, Murcia, 1979, págs. 453 y 504. MENENDEZ GONZALEZ, A.: "La venta de oficios públicos en Asturias en los siglos XVI y XVII", Boletín del Inst. de Estudios Asturianos, XXXVIII, 112 (1984), págs. 682 y ss. RODRIGUEZ FERNANDEZ, A.: Alcaldes y regidores:administración territorial y gobierno municipal en Cantabria durante la Edad Moderna, Santander, 1986, págs. 33 y ss. 
nos-primos-cuñados), pues cuando se transfieren a otros parientes o amigos es de forma provisional y siempre para conservarlos en tanto alcanza la mayoría de edad el auténtico heredero. Por supuesto no siempre aconteció de este modo, y los vínculos profesionales desempeñaron un destacado protagonismo en el mecanismo de las renuncias, aunando intereses y ganando voluntades, o lo que es lo mismo, rodeándose de una clientela para dominar el concejo, pero también para incardinarse en las instituciones políticas de la Monarquía. Así pues, el Regimiento madrileño se configura como una oligarquía de poder nobiliario que con el tiempo restringe cada vez más el acceso a familias de oscuro linaje, según se desprende del Estatuto de limpieza de sangre de 1603, no ratificado en verdad hasta 1638 .

La pertenencia al estamento nobiliario no implica forzosamente disfrutar de una posición económica desahogada.Nobleza y dinero no siempre van parejos y los testimonios literarios así lo resaltan. Las críticas coetáneas -en realidad más frecuentes desde finales del siglo XVI- contra los pecheros enriquecidos, sin duda inmisericordes y tal vez injustas, la defensa de los juristas y militares de la nobleza de las letras y las armas, la compra de oficios públicos como paso previo a la promoción social, son otros tantos signos de que existe en la sociedad castellana de la época un abismo profundo entre el ser noble y el ser rico o merecedor de una mayor estima social por los méritos personales. Esta dicotomía la vamos a encontrar asimismo entre los regidores madrileños, aunque, es verdad, bastante mitigada, en parte porque la nobleza de viejo cuño, es decir, los hidalgos afincados desde antiguo en Madrid necesitan dinero para sufragar los elevados gastos que se les originan a partir de la decisión de Felipe II de trasladar la Corte a la Villa, convirtiéndola de paso en la capital de la Monarquía ${ }^{6}$ y en parte también porque el dinero les permite comprar señoríos e incluso hábitos militares, catapultándoles así hacia la cumbre del estamento.

La posesión de un señorío fue un factor decisivo para un ennoblecimiento posterior y ésta, sin duda, es la razón que movió a muchos de nuestros protagonistas a desear obtenerlo, especialmente en los casos en que éstos procedían de las altas esferas de la Administración y pretendían una promoción social que el mero desempeño de sus oficios nunca les proporcionaría. Es el caso, por ejemplo, del Licenciado García Barrionuevo de Peralta, que en 1572 obtiene carta ejecutoria de hidalguía, en 1579 adquiere las villas de Fuentes y Valdesaz, y en 1609 logra un hábito de Santiago ${ }^{7}$. Análoga situación es la de Gabriel de Alarcón, pues según un testigo que depuso en las pruebas para ser nombrado caballero de Santiago, su padre Luis de Alarcón, tras adquirir la villa de Pozuelo de Aravaca y avecindarse en ella, "por ser hombres ricos y poderosos, se habían ido introduciendo en la hidalguía con favores y negociaciones".

El disfrute de un señorío, por pequeño que fuera, no sólo permitía a sus propietarios promocionarles hacia un hábito, sino, incluso, construirse unos orígenes hidalgos que con los años, y en una o dos generaciones, les aseguraba una posición privilegiada, una estima

6 Entre la abundante bibliografía al respecto, señalemos el reciente trabajo de ALVAR EZQUERRA, A.: El nacimiento de una capital europea. Madrid entre 1561 y 1606, Madrid, 1989.

7 Archivo Histórico Nacional (AHN), Ordenes Militares (OO.MM.), Expedientes de Santiago, 879. MOXO, S.: "Las desamortizaciones eclesiásticas del siglo XVI", A.H.D.E., 1, (1961), pág. 354.

8 AHN, OO.MM. Expedientes de Santiago, 183. 
social que les abría todas las puertas en su ascenso a una jerarquía superior. A este proceso, desde luego, también contribuyó el matrimonio y las herencias colaterales. Iñigo de Cárdenas Zapata que había recibido en mayorazgo la villa de Loeches, al contraer nupcias con Mencía de Cárdenas accede a los beneficios reportados por el señorío de Colmenar de Oreja - ésta lo aporta tras la muerte de su hermana, la Marquesa de Este9-. Gaspar Chacón es otro afortunado, pues al casarse con Isabel Ponce de León, hermana del también regidor Juan Ponce de León, entra a disfrutar del señorío de Polvoranza ${ }^{10}$. Del mismo modo, Gabriel de Alarcón incorpora al suyo de Pozuelo, los de Valdetorres del Jarama y Algete, heredados por su mujer Mariana de Garnica y Haro a la muerte del padre, el regidor Francisco Garnica, que los había adquirido en $1578^{11}$.

El salto siguiente, del señorío a la dignidad de título nobiliario, era ya muy fácil y más lo será en el reinado de Felipe IV y en el de su hijo Carlos II. En el período que estudiamos, aunque la concesión de esta merced no fue demasiado generosa, tenemos constancia de que varios regidores de Madrid la obtuvieron a modo de recompensa. Melchor Herrera es uno de ellos. Tras una brillante carrera al servicio de la Monarquía como Canciller de Castilla, Consejero de Hacienda y Tesorero General de Su Majestad, en 1582, nueve años después de comprar las villas de Auñón, Berlinches, Valdaracete y Valdemoro, es nombrado Marqués de Auñón ${ }^{12}$. Francisco Zapata de Cisneros es otro de los ennoblecimientos recientes. Heredó a la muerte de su padre la villa de Barajas, en 1572 se le otorgó el título de conde en premio a sus méritos personales demostrados sobradamente en el desempeño de varios cargos públicos: Corregidor en Córdoba, Asistente de Sevilla, Presidente del Consejo de Ordenes y luego del Consejo Real ${ }^{13}$. Pedro Franqueza, por último, sigue la misma trayectoria que los anteriores. Al amparo de una fulgurante carrera administrativa, jalonada con diversos cargos y culminada con una Secretaría de Estado y del Consejo de Inquisición, lo que le va a permitir, por procedimientos poco ortodoxos, acumular una importante fortuna, entra en poder de los señoríos de Villafranca, Benemeli, Merchán Tielmes, Romancos y Berlinches -éste último lo compró a los herederos del Marqués de Auñón en 1600- para ser elevado posteriormente, en 1603, a la dignidad de Conde de Villalonga con motivo de la boda de su hijo, el futuro regidor madrileño Martin Valerio Franqueza, además Conde de Villafranqueza, con la hermana del Conde de La Coruña ${ }^{14}$.

\section{BIENES PATRIMONIALES}

En conjunto, y salvo excepciones, por notables que sean, el patrimonio de los regidorés madrileños puede calificarse de elevado, y no precisamente por los sueldos devengados del

9 Archivo General de Simancas (AGS), Cámara de Castilla.Procesos y Expedientes, 1656-15.

10 Ibídem, 1634-5.

11 MOXO,S.: Op.cit., pág. 354.

12 AGS, Contaduría de Mercedes, 438-8. MOXO,S.: Op.cit., pág.343.

13 APM, Protocolos 203 fol. 42; 412 fol. 72; 416 fol. 527; 417 fol. 505. AGS, Quitaciones de Corte, 19. MARAÑON,G.: Antonio Pérez (El hombre, el drama, la época), Madrid, 1963, págs.160 y ss. BALLESTEROS RODRIGUEZ, J.: La peste en Córdoba, Córdoba, 1982, pág. 215.

14 Sobre ello, mi trabajo: "D. Pedro Franqueza y Esteve, de regidor madrileño a secretario de Estado", Pedralbes (en prensa). 
ejercicio de sus cargos en el municipio, pues apenas alcanzan los 2.000 maravedíes anuales, sin contar ayudas de costa y otros gajes por las comisiones que se les encargan ${ }^{15}$.

Por lo general, tanto los "cuerpos de hacienda" como los mayorazgos son evaluados entre seis y diez millones de maravedíes, si bien, desde luego, estas cifras fueron ampliamente superadas en algunos casos. Así, por ejemplo, los bienes libres de Juan Fernández fueron tasados en 49.039.510 maravedíes, los de Luis Hurtado en 19.745.563 maravedíes y Ios de Bernardino de Matienzo en 13.095.627 maravedíes $^{16}$. En cuanto a los mayorazgos, sabemos que el heredado por Gaspar Ramírez de Vargas ascendía a 28.800 .000 maravedíes y que el legado por el Marqués de Auñón a su hija excedía con mucho tal suma, pues por la villa de Valdemoro, que es enajenada al Duque de Lerma, para poder cancelar una parte de las deudas que pesaba sobre el vínculo, se pagaron 45.000.000 de maravedíes y por las dehesas de Acequilla y Casasolas, ofertó el regidor Alonso Muriel de Valdivieso, a quien se le ofrecieron, 8.250.000 maravedíes ${ }^{17}$. Indirectamente nos da idea del valor del mayorazgo de Diego Zapata de Mendoza el censo que impuso sobre sus bienes por un principal de 26.749.515 maravedíes y un interés del 7 ' $14 \%{ }^{18}$. Asimismo importante fue el patrimonio acumulado a lo largo de su vida por el Licenciado García Barrionuevo de Peralta, ya que aparte de constituir dos mayorazgos para sus hijos, compró a otro una secretaría real en Nápoles por la que desembolsó 15.000 .000 de maravedies y entregó en dote a su hija Luisa otros cinco millones y medio más ${ }^{19}$.

Los bienes que constituyen estos patrimonios son de muy diversa índole, aunque priman tierras, inmuebles, juros, oficios y, en menor cuantía, censos. Luis Herrera poseía 74 yuntas de tierras distribuídas en Carabanchel, Fuenlabrada, Vicálvaro y Getafe ${ }^{20}$, en tanto que Alonso Martínez de Cos transmite a su hijo un patrimonio rústico que se elevaba a nada menos que tres mil fanegas de tierra ${ }^{21}$. Pedro Vozmediano, a su vez, era propietario de fincas en el término municipal de la Villa y en los alrededores que le rentaban al año 600 fanegas de pan que, al precio de la tasa, le producían unos ingresos de 367.200 maravedíes - no incluimos aquí los beneficios derivados de la dehesa de Malpartida, en Colmenar del Arroyo-. Su nieto, el capitular Pedro González de Mendoza Vozmediano, obtenía de sus tierras, arrendadas a censo perpetuo, la suma de 1.309.000 maravedíes al

15 AVM, Contaduría, 1-160-5. Tengamos en cuenta que, a finales del siglo XVI, el salario de un peón era de 68 ducados y el de un maestro carpintero, 110 ducados, según lo pone de manifiesto BENNASSAR, B.: Op. cit., págs. 339 y 340 .

16 APM, Protocolos 2678; 595; 1832. Quizá nos sirva para comprender estas magnitudes la comparación con otros casos, como pueden ser los que presenta BENNASSAR, B.: Op.cit., págs. 126 y 127: entre las fortunas aristocráticas, las cantidades oscilan entre los $130.000 \mathrm{y}$ los 12.000 ducados; las fortunas de las familias "hidalgas", rondan los 21.000 ducados; los letrados entre los 40.000 y los 4.400 ducados; los hombres de negocios atesoran entre los 125.000 y los 6.7000 ducados; un platero entre los 15.5000 y los 1.200 ducados.

17 APM, Protocolo, 421 fol. 122. AGS, Cámara de Castilla. Procesos y Expedientes, 1631-7.

18 AGS, Cámara de Castilla.Renuncias, 2296.

19 Sobre ellos, mi trabajo "El parentesco en la formación de grupos de influencia en el concejo madrileño de la segunda mitad del siglo XVI: los Barrionuevo de Peralta", (en prensa).

20 APM, Protocolo 412 fol. 165.

21 Ibidem, 336 fol. 1096. 
año ${ }^{22}$. Con todo, el caso más sobresaliente es el del regidor Juan Fernández, cuya huerta, situada al final de la madrileña calle de AIcalá, con casas, lavadero, jardines, etc., 1625 tasada en en 22.327.902 maravedíes, sirviendo de lugar de recreo para las damas de la nobleza cortesana, entre las que se encontraba la esposa del Conde-Duque de Olivares ${ }^{23}$.

Los inmuebles son la segunda partida fundamental en la formación de los patrimonios, sobre todo de las familias de más antigua raigambre en la Villa, como los Mármol, Vitoria, Guevara, Ribera, Castilla, Luján, Monzón o Coalla, pues eran los propietarios de la mayor parte del suelo urbano madrileño ${ }^{24}$; inversión a la que se consagró también Sebastián Hurtado - algo más del $80 \%$ de su patrimonio estaba compuesto por bienes inmuebles-, o Diego González Henao, propietario de treinta y cuatro casas en diferentes barrios madrileños, aparte de las que constituían su vivienda ${ }^{25}$. Esto hizo posible, junto con la presencia de la Corte, que se produjese un alza desmedida en el precio de los solares y casas, devengando a sus titulares unos ingresos sustanciosos tanto si los alquilaban como si los vendían. Buena prueba de ello es que la vivienda adquirida por el padre de Francisco Alfaro fue evaluada en 4.500.000 maravedíes, mientras que Francisco Garnica vendió, en 1604, al Marqués de Malagón una de sus casas al precio de 11.250.000 maravedíes y Pedro Franqueza pagó cerca de doce millones por las que poseía Pedro de Medicis ${ }^{26}$. Por su parte, Pedro Fernández de Alarcón, alquila su "casa grande" de la calle de los Carmelitas Descalzos, para uso de los embajadores de Inglaterra y Persia, al precio de 675.000 maravedíes anuales ${ }^{27}$. No inferiores debieron ser las sumas obtenidas por Pedro Vozmediano, casero del maestro López de Hoyos, del Conde de Ricla y de altos personajes de los Consejos $^{28}$.

Para un sector nutrido de regidores la inversión se orientó preferentemente hacia la deuda pública consolidada. Es verdad que todos, en mayor o menor cuantía, participaron en este negocio -el 36'5\% de los capitulares obtienen unas rentas que no superan los 100.000 maravedíes-, pero fueron los hombres de negocios, los mercaderes y los altos funcionarios quienes desviaron mayores capitales, percibiendo unas rentas anuales que en algunos casos superan el millón de maravedíes -esto supone un principal en torno a los veinte millones de maravedies-, como el tesorero general del Reino, Melchor Herrera, el depo-

22 AGS, Cámara de Castilla.Procesos y Expedientes, 1769-13; Contaduría de Mercedes, 472-20.

23 APM, Protocolo, 2678, 2 de agosto de 1625. Una huerta, cuya importancia queda por sí sola puesta de manifiesto en la obra del maestro TIRSO DE MOLINA, La huerta de Juan Fernández, Sevilla, 1626. Edición de Berta Pallarés, Madrid, 1982.

24 CASTELlANOS, J. M.: El Madrid de los Reyes Católicos, Madrid, 1988, pág.90.

25 APM, Protocolos 595 fol. 107; 2296 fol. 296; 3774 fol.143.

26 AGS, Cámara de Castilla. Procesos y Expedientes, 1634-15. AHN, Consejos, 4414 núm. 16, año 1595. CABRERA DE CORDOBA, L.: Relación de las cosas sucedidas en la Corte de España desde 1599 hasta 16/4, Madrid, 1857, pág. 223.

27 APM, Protocolo 2013 fol. 286.

28 Ibídem, 392 fol. $460 ; 190$ fol. 122; 481. 
sitario general del Reino, Licenciado García Barrionuevo de Peralta, o el banquero Cosme Ruíz Embito ${ }^{29}$.

Los oficios acapararon, asimismo, elevadas sumas de dinero no sólo por el prestigio social que conllevaban o por la capacidad política que deparaban a sus titulares, sino incluso porque podian ser enajenados o arrendados, obteniendo así en el primer caso, unos ingresos fijos y, en el segundo, una revalorización del capital invertido, dada la cotización que alcanzan por la fuerte demanda existente en la época. En efecto, si en 1560 y 1561 Melchor Herrera y Alvaro de Mena abonan 300.000 maravedíes cada uno por sus respectivas regidurías, en 1606 Cosme Ruíz Embito, satisface por la suya la elevada cifra de 1.428.000 maravedíes $^{30}$. Esto explica que Juan Pinedo solicite de Juan Fernández un préstamo de 837.500 maravedíes al interés habitual, para comprar la regiduría de Gabriel Oviedo, a la sazón cuñado del edil Fernández, o que Diego de la Canal otorgase por idéntico motivo un censo a Diego de Urbina por un principal de 525.000 maravedíes a 14.000 el millar ${ }^{31}$. La situación es análoga en cuanto a los cargos de la Administración del Estado. Ya hemos señalado que el Licenciado García Barrionuevo de Peralta pagó quince millones de maravedíes por una secretaría de Italia para uno de sus hijos. No fue un caso aislado. Juan Carrillo de Albornoz, adquiría, tras haber servido como "capitán de las gentes de Huete" en la rebelión de los moriscos de Granada, la Escribanía Mayor de las Armadas de las Indias por un valor de 9.000 ducados $^{32}$. El deseo de acaparar estos oficios lo encontramos suficientemente representado en Juan Ruiz de Velasco, poseedor de dos regidurías madrileñas - ambas son vendidas, obteniendo con ello pingües ganancias-, dos oficios de la Casa de la Moneda de Sevilla y Cuenca, una ayudantía de Cámara, la escribanía mayor de Toledo, otra escribanía en Quito, dos secretarías reales, una regiduría en León y la alcaidía de Consuegra ${ }^{33}$.

\section{ESTILO DE VIDA}

Del patrimonio de los regidores madrileños podemos deducir, en gran medida, su modo de vida. En realidad, sin embargo, éste excedía con mucho al que permitía la fortuna familiar, pues en la sociedad castellana del siglo XVI se estimaba a la persona - y con ella al linaje- no por su valía intelectual o profesional, sino por su hidalguía y limpieza de sangre, pero también por lo que aparentaba, es decir, por los signos externos de riqueza. Las elevadas deudas contraídas por algunos capitulares obedecen a esta pauta de comportamiento,

29 A modo de ejemplo, Melchor Herrera, con 65.369.242 maravedíes de principal obtenía unos intereses anuales de 5.212.286 maravedíes. Barrionuevo de Peralta, desvió a la compra de títulos de deuda consolidada nada menos que 106.173.594 maravedíes, lo que, a un interés medio del 5'29\%, le reportaba unos ingresos anuales de 5.617.442 maravedíes. Cosme Ruíz Embito, acumuló entre 1597 y 1602 una renta de 9.072.647 maravedíes, lo que suponía un capital invertido de 172.961.443 maravedíes.Referencias sobre algunos de ellos en AGS, Contaduría de Mercedes, 562-25, 28, 35, 36; 559-39.

30 AGS, Cámara de Castilla. Oficios, 19. Cámara de Castilla.Procesos y Expedientes, 1646-48.

31 APM, Protocolos, 2623 fol. 1139; 300 fol. 1354.

32 AVM, Secretaría, 2-350-9.

33 AGS, Contaduría de Mercedes, 376-29. 
visible en las dotes de las hijas, muy superiores a las que habían aportado sus madres al matrimonio - clara manifestación a la vez del enriquecimiento de los padres y del proceso inflacionista que se sufre- ${ }^{34}$, así como en la servidumbre que mantienen, en los esclavos que poseen y, sobre todo, en la elección de la vivienda y en los objetos de lujo que atesoran.

Los altos precios pagados por el padre de Francisco Alfaro y por Pedro Franqueza nos indican el prestigio que para ellos representaba el poseer unas casas costosas. Sabemos, también, que el Licenciado García Barrionuevo se jactaba de haber sido el primero en construir su morada con "pilares y portada de piedra" 35 , y no son raras las viviendas que disponían de capilla u oratorio ${ }^{36}$. En líneas generales, los edificios constaban de dos plantas y disponían de un mínimo de cuatro habitaciones, "retrete", cocina, patio y, en algunos casos, jardines adornados con fuentes, aparte de otras dependencias que servían de bodega y cochera $^{37}$. Mas si costoso era adquirirlas, no menos resultaba mantenerlas en perfecto estado de conservación por la carestía de los materiales y de la mano de obra. Es muy revelador que en 1574 Pedro Rodriguez de Portocarrero desembolse por diversos trabajos de albañilería y carpintería 300.455 maravedíes y que, por las mismas fechas, Iñigo López de Mendoza tenga que pagar 187.500 maravedíes por varias reformas de poca monta en las casas que servían de residencia al presidente del Consejo de Castilla ${ }^{38}$. Simplemente ajustar el tamaño de las rejas de su casa a las normas estipuladas por la Junta de Urbanismo supuso a San Juan de Sardaneta el coste de 31.451 maravedies $^{39}$.

Si las fuentes son parcas en lo que se refiere a los materiales de construcción y estructura interna de las viviendas, son más generosas con aquellos objetos que las decoraban o

34 Melchor Herrera, por ejemplo, a su muerte, dejaba unas deudas que superaban los noventa millones de maravedíes, AGS, Cámara de Castilla. Procesos y Expedientes, 1629-19. Francisco Zapata de Cisneros, adeudaba unos quince millones de maravedíes por diversos conceptos, AGS, Cámara de Castilla, Renuncias, 2296. Deudas elevadas, sin duda, que en ocasiones vienen motivadas por el pago de elevadas dotes matrimoniales de los hijos. Asî Francisco Martinez padecía una situación delicada por haber destinado a los casamientos de sus hijos, habidos de dos matrimonios 23.500 ducados, APM, Protocolo 2625 fol. 888. Juan Vázquez de Salazar había recibido cuando contrajo matrimonio 1.725 .000 maravedíes en dote, sin embargo a su hija la regalaba 2.250.000, APM, Protocolo, 2602. Melchor Herrera, tan sólo recibió 375.000 maravedíes y en su testamento, expresaba la voluntad de dotar a cada una de sus dos hijas con la desorbitada cifra de trece millones, aproximadamente.

35 AHN, OO.MM. Expedientes de Santiago, 878.

36 Así, las viviendas de Pedro Fernandez de Alarcón, Luis Hurtado, Juan Fernández, Luis de Peralta, Juan Ruíz de Velasco, Juan Hurtado de Mendoza e Iñigo de Cárdenas, entre otros. Acceso directo de la casa a la iglesia parroquial, a través de una ventana, lo encontramos en la vivienda de Diego Zapata de Mendoza, APM, Protocolo, 2631.

37 Respecto a los jardines, eran más frecuentes en las casas que estaban situadas a las afueras del casco urbano.Citemos como ejemplo las casas de Juan Fernández y de Luis Hurtado, APM, Protocolos, 2678 y 595. Sobre el fasto de las casas de los "principales" en la época, una magnífica descripción en MARAÑON, G.: Op. cit., pag. 56. SIMON DIAZ, J.: "El arte en las mansiones nobiliarias de Madrid", Goya, (1980).

38 APM, Protocolo 411 fol. 268. AVM, Contaduría, 1-252-2, año 1595.

39 ANDRES, G.: "Ordenación urbanística de Madrid dada por Felipe II en 1590", A.I.E.M, XII (1976), pág. 25. APM, Protocolo, 192, fol. 3. MARTINEZ BARA, J.A.: "Algunos aspectos del Madrid de Felipe II", A.I.E.M., III (1968), págs. 17-21: el 16 de octubre de 1587, la Villa proponía al Consejo los siguientes precios: la cal en invierno a 27 reales el cahíz, en verano a 24; el cahíz de yeso, en invierno a 18 reales y en verano 16; el millar de ladrillo, mitad pardo, mitad colorado, en inviemo 66 reales y en verano 55; todos estos precios a condición de poner los vendedores el material al pie de la obra, sin pedir ni llevar mayor cantidad.. 
que satisfacían las necesidades cotidianas. Conviene señalar - y esto aparece estrechamente asociado al prestigio social- la escasa atención que prestaron a los enseres domésticos y el realce, en cambio, de los muebles, tapices y cuadros, pues éstos absorbieron por término medio entre un 10 y un $15 \%$ del valor de los bienes que poseían, aun cuando personajes tan ricos como Pedro de Guzmán y Francisco de Peralta destinan sólo un 5\% de su patrimonio, en tanto que el vestuario, joyas y metales preciosos adquiere una mayor estima en sus haciendas ${ }^{40}$. Mesas, taburetes, sillas, bancos, estanterías para libros, celosías, alacenas, arcas y cofres -estos últimos traídos en ocasiones de Flandes o de Alemania-, armarios, camas y escritorios -los hay de ébano y marfil-, son las piezas tradicionales que se encuentran en las casas. Sin embargo, la belleza o calidad de sus materiales -predomina el nogal sobre el pino, los cueros repujados y los atachuelados- es la que va a determinar las diferencias entre unos hogares y otros, y, en consecuencia, la riqueza, real o aparente, de sus propietarios. El mejor ejemplo lo tenemos en la cama, pues en conjunto son evaluadas en torno a los 100.000 maravedíes, aunque las hay más costosas, como la de Juan Fernández, que abonó por ella 317.560 maravedíes, la de Pedro de Guzmán, encargada a unos artífices italianos, por la que pagó 562.000 maravedíes, o la de Pedro de Lodeña, quien a su vez invirtió en esta pieza y sus aderezos la cifra de 626.926 maravedíes $^{41}$.

El complemento perfecto para estos muebles son los tapices, alfombras y cuadros y, según se desprende de la documentación, no fueron considerados meros accesorios, ya que las inversiones efectuadas en ellos superan, a veces, las realizadas el mobiliario. Las alfombras, normalmente cuatro por hogar, procedían de Alcaraz y Turquía. Los tapices suelen venir de Flandes, sobre todo de Brujas y Amberes, aunque, curiosamente, en algún que otro caso, fueron fabricados en Indias ${ }^{42}$. Por lo general, representan paisajes, figuras de la Antigüedad, motivos religiosos, monterías, segadores y bodegones. Estos temas aparecen asimismo en los cuadros, si bien los retratos ocupan un lugar privilegiado como se deduce de las pinacotecas de Juan Fernández y de Pedro de Guzmán ${ }^{43}$. El precio medio en que son tasados ( en torno a los 44 y 66 reales), no puede ser más revelador de que la mayor parte de ellos son el producto de un fenómeno que acababa de nacer a partir del interés progresivo desarrollado alrededor del género pictórico: la pintura "en serie"

El aprecio de los metales nobles en la Castilla del siglo XVI motivó que se destinaran fuertes sumas a joyas, oro y plata, inversión no productiva, en efecto, pero en absoluto carente de rentabilidad. Las colecciones más espléndidas coinciden con los regidores más hacendados, manifestándose una proporción equilibrada en la elección de joyas de oro y de plata, con sólo dos excepciones, Pedro de Guzmán y Francisco de Peralta, que se muestran

40 APM, Protocolos 2604 fol. $38 ; 3770$ fol. 867.

41 Ibídem, 293 fol. 1332; 2604 fol. 38; 2678.

42 Es el caso de los que posee el regidor Francisco Prado, Ibídem, 384.

43 Pedro Guzmán atesoraba nada menos que ochenta retratos: 40 de Papas, 7 de emperadores y reyes, 17 de famosas personalidades y el resto de mujeres principales, Ibídem, 2604 fol. 38. Entre los de Juan Fernández, destaquemos los de diversos reyes, papas y célebres individuos otomanos, Ibídem, 2678.

44 Tan sólo hemos encontrado un cuadro que supera por sí mismo los 400 reales, representando a Nuestro Señor con la cruz a cuestas, Ibidem, 2678. CHECA, F.: Pintura y escultura del Renacimiento en España, 1450-1600, Madrid, 1983. 
preferentemente inclinados al primer grupo. Estos objetos parecen obedecer a exquisitas obras de orfebrería y los 735.216 maravedíes invertidos en ellas por el primero se justifican plenamente: cadenas de oro, distintas veneras -la más grande, esmaltada con la cruz del Hábito de Santiago y con el "asa" hecho en Milán, alcanza un valor de 613 reales-, medallas, aderezos de sombreros, más de mil perlas, casi cuatrocientos botones de oro, y la pieza más cara, un cintillo con veintitrés diamantes evaluado en más de noventa mil maravedíes. Por lo que respecta a la plata, tanto blanca como dorada, se reparte en platos, fras$\cos$, confiteras, escudillas, candelabros, cucharas, naranjeros, cantimploras, aceiteras y vinagreras, saleros y azucareros ${ }^{45}$.

La importancia concedida a los vestidos en los inventarios "post-mortem" o en las escrituras de capitulaciones matrimoniales es significativa. Idéntica consideración se puede establecer hacia la denominada "ropa blanca", es decir, aquella que conformaba el ajuar propiamente del hogar (sábanas, toallas, almohadas, servilletas, manteles, "lienzos de narices", etc.). No obstante, se aprecia una mayor valoración en lo que al vestuario de ia mujer se refiere, de lo que parece deducirse que la fuerza coactiva de la moda tuvo más incidencia sobre la población femenina: tan sólo seis vestidos de María Olalde, mujer de Juan Fernández, valían 646.334 maravedíes (el 17\%\% del total de los bienes). La riqueza, el lujo de los mismos, sus bordados en oro y plata lo justifican, aunque, según palabras del tasador, muchos de ellos fueran de "chicha y nabo" 46 . El vestuario de los regidores era bastante más humilde, salvo cuando se trataba de participar en actos solemnes de la Villa, para lo que contaban con la financiación del concejo. Habitualmente, siguieron los dictámenes del momento, según lo describe un cortesano de Madrid en 1586:

"...Los trajes de la gente principal son las calças tudescas, las cinturas como frayles Bernardos, un palmo más arriba del estómago, los sombreros a la francesa, las lechuguillas a la portuguesa, los rostros y copetes a la italiana, las capas y espadas españolas..." 47 .

Los coches, sin duda, fueron elementos esenciales de ostentación social. Pese a no estar por estos años aún muy difundidos, no por ello hemos dejado de recoger testimonios de algunos capitulares que sí los tuvieron, lo que demuestra, al igual que ocurría en Valladolid por las mismas décadas, que estaban reservados para las élites más privilegiadas de cada localidad $^{48}$. Los precios medios oscilaron en torno a los 15.000 maravedíes y la mayoría eran de cuatro ruedas, tirados por dos caballos y guarnecidos de lienzo o forrados de balleta. La excepción, una vez más, la presenta Juan Fernández pues su carruaje fue tasado en 51.500 maravedíes $^{49}$. Junto a éstos, caballos y armas completan los inventarios madrileños.

45 El total del valor de bienes inventariados asciende a 6.342 .014 maravedíes, APM, Protocolo 2604 fol. 38. En el segundo caso, el inventario se valora en 2.227 .460 maravedíes, Ibídem, 3770, fol. 867.

46 Ibídem, 2678.

47 Biblioteca Nacional de Madrid (BNM), Manuscritos, 1761.

48 BENNASSAR, B.: Op. Cit., pág. 428.

49 APM, Protocolo, 2678. 
El afán por rodearse de una servidumbre numerosa, aunque fuese innecesaria, es un signo evidente de ostentación que dignificaba al patrón. A pesar de que no resulta fácil conocer con precisión el número de criados de los que se rodearon los regidores, hemos podido establecer una media aproximada en torno a los 3'8 servidores por cada una de las familias. Como siempre, esta cifra encubre grandes oscilaciones, ya que los capitulares más acaudalados y con mayores influencias en la Administración son los que acaparan un porcentaje más elevado -de Melchor Herrera, se llega a decir que había tenido más de doscientos criados en el apogeo de su esplendor y fortuna ${ }^{50}$-. En cuanto a las funciones o tareas de los criados, éstas eran muy variadas, observándose entre el servicio masculino una compleja jerarquía que se distinguía no sólo por los honorarios percibidos sino también, al menos teóricamente, por sus competencias. Así, encontramos mayordomos, pajes, escuderos, lacayos y, entre el personal subalterno, cocineros, despenseros, cocheros, guardas y jardineros. Respecto al servicio femenino y siempre, insistimos una vez más, entre los capitulares de mayor poder adquisitivo, encontramos a las amas de cría, pues hasta el siglo XIX, en que las mujeres urbanas en España comenzaron a criar personalmente a sus hijos, estaba mal visto que una madre se dedicara a tal menester sobre todo si gozaba de una posición privilegiada ${ }^{51}$. El lustre y la consideración de que podía ser objeto una familia por el hecho de tener muchos criados se crecía si, además, eran dueños de esclavos. El esclavo empleado en el servicio doméstico era motivo de ostentación, un objeto de lujo. Entre los regidores madrileños, lo habitual fue tener uno, aunque conocemos excepciones, como la que representa Pedro Herrera, dueño de cuatro, o Garcí Mazo de la Vega, propietario de tres -una pareja y su hijo- ${ }^{52}$. En la mayor parte de los casos gozaron de igual consideración que los criados y, por lo tanto, disfrutaron del mismo aprecio y de idéntica protección por parte de los amos, según se desprende de la siguiente cláusula del testamento de Juana Calderón, esposa de Luis de Peralta:

" por el buen serbizio que de ella he tenydo, (mi esclava negra Francisca) quede libre porque es bieja y no puede trabaxar, y el suçesor de mi mayorazgo quiero que, hasta que ella muera, le de de comer y cama, de la manera que yo lo hago agora, y quatro ducados cada año para que se bista"s3.

\section{TRABAJO Y OCIO}

Las múltiples necesidades derivadas del asentamiento de la Corte en Madrid desde 1561, en cuanto al abastecimiento, limpieza y urbanismo de la Villa se refiere, alteraron de forma significativa el ritmo de trabajo de los regidores. Los consistorios, que en un principio se realizaban los lunes, miércoles y viernes, salvo en Cuaresma, que tenían lugar los martes y jueves, se incrementaron poco a poco, hasta el punto de ser sacrificados los ofi-

50 BNM, Manuscritos, 3412.

51 VIGIL, M.: La vida de las mujeres en los siglos XVI y XVII, Madrid, 1986, pág. 129.

52 APM, Protocolos, 286 fol. 410; 5038.

53 Ibidem, 590 fol. 912. 
cios religiosos característicos de estas fechas en beneficio público, celebrándose sesiones a diario e, incluso, los domingos. De hecho, entre 1560 y 1606 se convocaron 6.174 cabildos, entre ordinarios, extraordinarios, abiertos y particulares, lo que arroja una media anual de 133 reuniones, muy superior a la que se daba en Murcia o en Cáceres ${ }^{54}$. Los meses de abril o marzo, según cayese la Semana Santa, y el mes de diciembre, son los que menos consistorios registran; los que más, junio, julio, agosto y septiembre. En cuanto al horario, éste era de 9 a 11 en invierno y de 8 a 10 en verano. Su coincidencia con el establecido en los Consejos ${ }^{55}$, explica en gran medida que quienes desempeñaban cargos en la Administración estatal no pudieran acudir a las sesiones municipales. Así no es extraño encontrarnos con que los regidores asisten por término medio al $38^{\prime} 6 \%$ de los consistorios celebrados $^{56}$.

Pero, al margen de estas reuniones, donde se debatían los asuntos de mayor interés para el concejo, los ediles debían cumplir otros cometidos que se les asignaban: nos referimos a las comisiones de abastos, pósito, puertas, hospitales, relojes, fuentes, obras y empedrados, limpieza, rentas reales, visitas de tierras, montes, barcas y festejos, aparte de patronatos y otras de carácter extraordinario con motivo de la celebración de Cortes, o de la amenaza de una epidemia. Su obligatoriedad fue motivo de conflictos continuos por cuanto que la mayoría no estaba dispuesta a ejercerlas, bien por incompatibilidad con otros cargos públicos, o para dedicarse de lleno a sus negocios particulares, ya que la firma de un préstamo, el cobro de los intereses de un censo, o la reclamación de los réditos impagados de un juro en el Consejo de Hacienda, eran operaciones que sólo podían realizarse por la mañana, precisamente en las horas en que se les exigía estuviesen dedicados al gobierno de la Villa. De este modo, un buen número de comisiones recayó en unos pocos regidores, como así sucede en 1565, en que Pedro Herrera se ocupaba de la custodia de la Puerta de Guadalajara, de la "puente" de San Jerónimo, del empedrado de diversas calles y del barranco que iba a la calle Arenal. Esta desigualdad ocasionó en 1567 graves enfrentamientos de palabra entre los capitulares, cuyas voces se escuchaban "en la plaza", razón por la cual el corregidor se vió precisado a imponer, bajo pena de sanciones, "moderación y templanza"

No todo, sin embargo, fue trabajo. Los regidores, al igual que los altos funcionarios, dedicaron parte de su tiempo, porque así lo exigía la posición privilegiada que gozaban, pero también por vanidad, a estar presentes en cuantas fiestas y regocijos se programaban en honor de la Casa Real o en acción de gracias por el triunfo del ejército en el campo de ba-

54 CHACON JIMENEZ, F.; Op. cit., pág. 464. SANCHEZ PEREZ, J.A.: Op. cit., pág. 89.

55 FAYARD, J.: Los miembros del Consejo de Castilla (1621-1746), Madrid, 1982, págs. 104-106. En el Consejo de Castilla, el horario era de 8 a 11 en invierno y de 7 a 10 en verano, de lunes a sábado, exceptuando las fiestas religiosas de precepto, fiestas de Corte, Semana Santa y Navidad.

56 La determinación de las variables estadísticas que se muestran en nuestro trabajo, se ha realizado empleando la aplicación informática SYMPHONY versión 2.0. Hemos partido del examen pormenorizado de los Libros de Acuerdos del concejo madrileño correspondientes a los años 1560 a 1606, para obtener en cada una de las sesiones celebradas la asistencia de los regidores; las asistencias mensuales han sido divididas entre el número de consistorios convocados, resultando así el porcentaje de participación de los capitulares para este mismo período de tiempo.

57 AVM, Libros de Acuerdos, sesiones del 18 de mayo de 1565 y del 13 de junio de 1567. 
talla, como juegos de cañas, encamisadas, procesiones religiosas -la del Corpus, por ejemplo-, representaciones de comedias, parabienes y recibimientos, tal que el dado en 1570 a la reina Ana ${ }^{58}$. Sus mujeres, en cambio, más apartadas de la vida pública, aunque casi siempre están presentes en festejos lúdicos organizados por el concejo, pasaban su vida regentando sus casas, asistiendo a la iglesia o visitando a las amigas, costumbre ésta muy extendida entre las damas pertenecientes a los estratos altos y medios de la sociedad urbana, donde eran agasajadas con dulces y refrescos, pasando la velada distraídas con charlas, juegos y tal vez algo de música. Quizá por esto aparezcan en los inventarios de los regidores arpas, llautas, guitarras, rabelas, bajones y cornamusas, así como tableros de ajedrez ${ }^{59}$.

La lectura, sobre todo entre los hombres, debió lienar las primeras horas de la mañana y de la tarde. La importancia de ciertas bibliotecas así lo parece indicar, si bien las obras almacenadas en los anaqueles se relacionan, en la mayoría de los casos, con la profesión de sus dueños. Más del 92'5\% de los libros de Agustín Alvarez de Toledo -su número asciende a 297 títulos y 405 volúmenes- versaban sobre cuestiones jurídicas, porcentaje que se observa asimismo en las bibliotecas de los licenciados Francisco Barrionuevo de Peralta, Bernardino Matienzo y Francisco de Peralta ${ }^{60}$. Cuando los propietarios no son letrados, las obras que adquieren presentan una variación mayor, como se deduce de las que posee Luis Hurtado, pues de un total de 119 libros, más de la mitad son de literatura, clásica o renacentista, distribuyéndose el resto entre libros profesionales, Gramática, tratados de Historia y de Filosofía, manuales de Derecho, devocionarios y vidas de santos. Por el contrario, la biblioteca de Pedro Fernández de Alarcón cuenta sobre todo con libros de carácter piadoso, los cuales ocupan un lugar destacado entre la lectura de la mayoría de las esposas de los regidores buena muestra, en suma, del sello que imprime la religión en sus vidas ${ }^{61}$.

\section{EL RITUAL DE LA MUERTE}

Aunque no todos los ediles manifiestan un interés especial por la ostentación , sí se observa, en cambio, una misma actitud en las disposiciones testamentarias relativas al sepelio y, sobre todo, en las fundaciones de monasterios, capellanías, colegios y obras pías. Es verdad que con estos legados se trata de facilitar la salvación del alma, ayudando de paso a personas pobres, fueran o no de su familia, pero no es menos cierto que con ellos se pretende recordar, a quienes se benefician, la bondad del donante. El reconocimiento por parte de los cristianos de la caducidad de la vida terrenal en contraste con la eternidad de su alma les llevará por un lado, a establecer, antes de su muerte, los medios adecuados para su salvación y, por otro, el lugar donde deberán reposar sus cuerpos en espera de la Resurrección. Guiados por estas creencias, no sólo dispondrán la celebración de oficios religiosos por su alma sino que también detallarán con todo cuidado el lugar exacto de su enterra-

58 Con este motivo se celebran 177 consistorios anuales.

59 APM, Protocolos 595; 1427; 2615; 1808. VIGIL, M.: Op.cit., págs. 156 y ss.

60 Ihidem, 1262; 1832; 580. BENNASSAR, B.: Op. cit., pág. 472-485.

61 APM, Protocolos, 595; 2013. 
miento $^{62}$. Esta filosofía ante la muerte contribuirá a marcar diferencias estamentales en el momento de determinar el lugar de sepultura, constituyéndose todo un mundo de jerarquías alentado por el ceremonial mortuorio.

Seguramente el hecho de que los capitulares procedieran de familias arraigadas desde antiguo en la Villa, les llevó a edificar sus sepulcros en las iglesias de las parroquias donde vivían, con preferencia sobre los conventos ${ }^{63}$. Algunos son propietarios de capillas, constituyendo un pequeño coto de riqueza familiar, no sólo por las rentas con que las fundan y mantienen, sino porque se convierten en pequeños centros de coleccionismo artístico, con los que se pretendía individualizar el lugar exacto donde descansar su eterno sueño el difunto, al mismo tiempo que magnificarle. Esto se confirma, de otro lado, por la multitud de objetos que se legan a las capillas para su ornato, aparte, desde luego, los adornos tallados en piedra, las sepulturas de mármol con figuras yacentes u orantes y las pinturas que cuelgan de las paredes. Algo que las convierte asimismo en pequeñas, aunque sacras, "cámaras de maravillas", análogas a las que sabemos había en muchas viviendas. En este sentido se puede recordar una de las mandas testamentarias de Ladrón de Guevara:

"Iten mando que todas las reliquias que yo tengo, después de los largos días de mi señora doña Leonor de Zuñiga, mi muger, se pongan en la dicha mi capilla, en la pared que está enfrente del altar della que, aunque dixen que es el estribo que tiene la iglesia, se puede tomar muy poco hueco, que bastará hasta medio pie. $Y$ esto suplico a la dicha mi señora doña Leonor lo vaya haciendo con su comodidad y poniendo en tal ornato que sea en pieças que, el día de proçesiones, las puedan llevar en la mano sacerdotes revestidos, y tenga la llave de las dichas reliquias el prior del dicho convento, y póngase un letrero arriba y abajo de las reliquias en que se ponga, en lo alto, los nombres de mis padres y en lo bajo, el mío y de mi muger"64.

Preferentemente eligen ser amortajados con el hábito de San Francisco, aunque los hay que piden ser vestidos con sus respectivos hábitos militares ${ }^{65} \mathrm{y}$, con el mismo interés, disponen una serie de medidas concretas sobre el acompañamiento del cortejo, cuyas características son similares a las observadas por Baudilio Mallón en Asturias o por Gadow en la

62 ROMANO, R. y TENENTI, A.: Los fundamentos del mundo moderno, Madrid, 1979, pág. 104. VOVELLE, M.: La mort et l'occidente de 1300 a nos jours, París, 1983, págs. 179-357. ARIES, Ph.: La muerte en Occidente, Barcelona, 1982, pág.115.

63 Por el contrario, en Málaga durante el siglo XVIII los miembros de las capas privilegiadas demandaban ser enterrados en los conventos, REDER GADOW, M.: Morir en Málaga. Testamentos malagueños del siglo XVIII, Málaga, 1984, pág. 136. Esta tendencia también se observa entre los consejeros de Castilla durante la misma época, en la etapa precedente, sin embargo, un elevado porcentaje deseaba ser enterrado en sus lugares de origen, FAYARD, J.: Op.cit,, págs. 482-483. Por el contrario, LORENZO PINAR, F.J.: Actitudes religiosas ante la muerte en Zamora en el siglo XVI: Un estudio de mentalidades, Zamora, 1989, pág. 40, observa idéntico proceso al que se produce entre a élite de poder madrileña.

64 APM, Protocolo, 1410 fol. 387.

65 AGS, Contaduría de Mercedes, 376-29. 
ciudad de Málaga en el siglo XVIII'66. Quienes optan por un ritual sencillo lo hacen en el convencimiento de que la pompa y vanidad mundana son contrarias a la humildad cristiana; curiosamente muchos de los que abogan por este tipo de ceremonial son destacados miembros de la burocracia, poseedores de considerables fortunas. Así Juan Ruiz de Velasco, secretario de Corte y deudo del Duque de Lerma, ordena ser trasladado al monasterio por él fundado "con el menor ruydo y aplauso" posible ${ }^{67}$.

Asimismo, el interés de los testadores por consignar el número de misas que se deben dar para la salvación de su alma, se refleja en todos los testamentos, indicándonos de pasada la riqueza del difunto. En nuestro caso, la media de misas encargadas se sitúa alrededor de Ias $1600^{68}$. -una notoria excepción la representa Melchor Herrera que dejaba estipulada la celebración de $20.000^{69}$. - , cifra que obedece al peso que tiene en la vida religiosa de los españoles la doctrina establecida en Trento, pero también el deseo de ostentación de las familias de regidores que han logrado un protagonismo destacado entre la elite local y en la Corte. Estas misas por la salvación del alma obedecen a una tipología determinada, según con la intencionalidad que se encarguen ${ }^{70}$, y de ellas queremos destacar las que han venido en denominarse de "fundación", toda vez que para su celebración se aseguraba una cantidad fija de dinero, casi siempre a invertir en valores rentables, por las instituciones que la recibían a cambio de oficiar determinadas misas y, por tanto, exceden con mucho la función primigenia de salvar el alma del difunto o de otros parientes convirtiéndose en obras de caridad y hasta en "beneficios" a los familiares pobres, con el único requisito de ordenarse de menores: nos estamos refiriendo a las memorias espirituales, capellanías, etc. La preferencia por unas u otras, sin embargo, no dependía tanto de la voluntad de los testadores como de sus fortunas.

Respecto de las memorias espirituales, las dotaciones variaban enormemente, pues iban desde los dos ducados de renta anual que estipula en su fundación Diego Zorita en 1571 -el beneficiario es el convento de Nuestra Señora de Atocha-, hasta los 64.800 maravedíes que otorga la esposa de Juan Ruíz de Velasco ${ }^{71}$. En la que instituye en 1598 el Licenciado García Barrionuevo de Peralta en la iglesia del monasterio de San Salvador de Oña, en Burgos, de la orden benedictina - justifica su elección por tratarse de un monasterio apartado, con pocas cargas y donde los sesenta monjes que viven no tienen la mayor parte del año por quién decir misa-, se consigna un juro al quitar de 2.040 .000 maravedíes a razón

66 REDER GADOW, M.: Op. cit., pág. 108. BARREIRO MALLON, B.: "La nobleza asturiana ante la muerte y la vida", Actas del II Coloquio de Metodología Histórica Aplicada, Santiago de Compostela, 1984, Vol. II, pág. 35.

67 AGS, Contaduría de Mercedes, 376-29.

68 En el caso de la nobleza asturiana del siglo XVI, la cifra se sitúa en 205, BARREIRO MALLON, B.: Op. cit., pág. 41. Para los consejeros de Castilla, desde el reinado de Felipe IV en adelante, la media está en 4.000, FAYARD, J.: Op. Cit., pág. 485.

69 APM, Protocolo, 1985 fol. 1286.

70 Fundamentalmente existen dos tipos de sufragios: las misas de "intención" y las de "dedicación" que podian efectuarse en un "tiempo corto o medio y en otro largo", según la clasificación de BARREIRO MALLON, B.: Op. cit, pág. 49.

71 APM, Protocolos, 1838 fol. $1280 ; 2464$ fol. 1258. 
de 20.000 al millar, situado sobre las alcabalas de Madrid - para que se le recuerde, en la escritura de fundación establece que se deberá colocar una tablilla con su nombre en la sacristía, protegida con una reja, y a la vista del sacristán y de los frailes- ${ }^{72}$.

Una finalidad parecida tuvieron las capellanías, institución de carácter piadoso pero con enormes repercusiones en el sistema financiero de la época, ya que sus fundadores, para asegurarse mejor la salvación eterna mediante las misas que los capellanes oficiasen, y cuyo número se especifica casi siempre en las escrituras de fundación, desvían una suma importante de capital en detrimento de inversiones cuya rentabilidad incida de manera positiva en la dinámica económica del país ${ }^{73}$. Junto a las capellanías hubo un tipo de instituciones de carácter benéfico que satisfacían, también, las exigencias de sus fundadores en cuanto a garantizar la salvación de su alma: nos referimos a los patronatos para casar o tomar estado las huérfanas necesitadas, y los colegios - Brianda de Mendoza, esposa de Luis Herrera, funda uno en Horche, Guadalajara, para cuyo efecto lega un juro situado en las salinas de Atienza por un principal de 8.000 ducados y una renta anual de $400^{74}$. La fundación de conventos reviste asimismo una gran importancia en los testamentos, y de éstos cabe resaltar el qua fundan Juan Ruíz de Velasco y su esposa, Isabel Nevares de

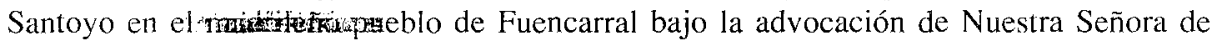
Valverde $^{75}$. Disposiciones, en fïn, para la construcción de monasterios aparecen, entre otros, en los testamentos de Gaspar Ramirez de Vargas y Lope Zapata de León: el primero indicando que se erija en la villa de Acebrón, el segundo ordenando que se levante en el lugar de Rejas en honor de la Anunciación de Santa Clara ${ }^{76}$.

Los regidores madrileños, en su mayoría integrados en el estamento nobiliario, aun cuando muchos tienen litigada su hidalguía, se presentan como un grupo de poder homogéneo que gobierna el concejo sin casi fisuras, mostrando estrechas relaciones con la Corona a través de los burócratas que forman parte del mismo. Este fenómeno, reforzado por lazos de parentesco, clientelas profesionales e intereses comunes sedimentados a través de la actividad diaria al frente del ayuntamiento, incide, a su vez, en unas formas de vida semejantes y en unas actitudes análogas ante la muerte, presididas por el prestigio de sus cargos en la comunidad que regentan y en las instituciones de gobierno de la Monarquía. Esto nos permite comprender las escasas diferencias que encontramos en sus hogares, forma de vestir o en el ritual mortuorio que explicitan en sus testamentos. Sólo el grado de fortuna acentúa desigualdades materiales, pues los hábitos que la sociedad atribuye al colectivo son asumidos de manera unánime por cada familia que lo integra, prueba palpable de la cohesión que manifiesta esta oligarquía de poder ante sus conciudadanos.

72 Ibidem, 1627 fol. 51.

73 GARCIA-ABASOLO GONZALEZ, A.F.: "Inversiones indianas en Córdoba. Capellanías y patronatos como entidades financieras" Actas de las II Jornadas de Andalucia y América, Sevilla, 1983, págs. 427453.

74 APM, Protocolo, 2627 rol. 822.

75 Ibidem, 2464 fol. 1203.

76 lbidem, 982 fol. $792 ; 384$. 